\title{
INCIDENCE OF OROFACIAL CLEFTS IN THE SLOVAK REPUBLIC
}

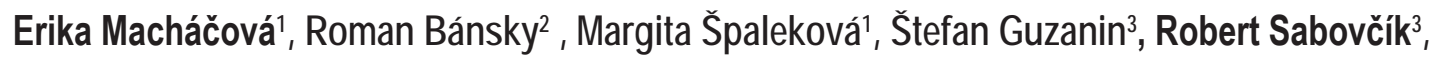 \\ Ladislav Slobodník ${ }^{4}$ \\ IInstitute of Epidemiology, Medical Faculty, Comenius University, Bratislava, Slovak Republic \\ ${ }^{2}$ Clinic of Plastic Surgery, Medical Faculty, Comenius University, Bratislava, Slovak Republic \\ ${ }^{3}$ Clinic of Plastic and Reconstructive Surgery, Medical Faculty, P.J.Šafarik's University, Košice, Slovak Republic \\ ${ }^{4}$ Department of Plastic, Estetic and Reconstructive Surgery, F.D. Roosvelt’s Faculty Hospital, Banská Bystrica, Slovak Republic
}

\begin{abstract}
SUMMARY
Orofacial clefts $(\mathrm{OC})$ are quite common congenital defects. Retrospective active survey collecting clinical data of children with $\mathrm{OC}$ examined and operated on in the three main specialized departments of plastic surgery in the Slovak Republic over 16 years (1985-2000) revealed total incidence of $1.61 / 10^{3}$ live births (LB). 1,849 children suffering from $O C$ were recognised out of $1,147,236$ live births.

Total incidence (TI) of OC per 1,000 live births was determined by types, gender, regions, districts and seasonal variation. The highest rate, $40.5 \%$ of clefts, affected the primary and secondary palate (CLP), more than $32 \%$ were of cleft palate type (CP), about $26 \%$ cleft lip (CL) and about $1 \%$ of associated malformations (AM). Clefts in males $\left(1.71 / 10^{3} \mathrm{LB}\right)$ were significantly more common than in females $\left(1.50 / 10^{3} \mathrm{LB}\right)$, sex ratio 1.14:1. Morbidity rates (TI) varies from $1.29 / 10^{3} \mathrm{LB}$ in the east Slovakia to the highest incidence of $1.93 / 10^{3} \mathrm{LB}$ in the middle Slovakia with wide range by district.

Comparing data from the study and from the national register, $17 \%$ of children with $\mathrm{OC}$ were missed. Presented survey assessed risk of $\mathrm{OC}$ in Slovakia at the rate 1 newborn with OC per 620 LB compared with notified frequency of 1 OC per 745 LB.
\end{abstract}

Key words: incidence, orofacial clefts, live births, Slovakia

Address for correspondence: Erika Macháčová, Institute of Epidemiology, Medical Faculty, Comenius University, Špitálska 24, 81372 Bratislava, Slovak Republic. E-mail: erika.machacova@fmed.uniba.sk

\section{INTRODUCTION}

In Slovakia, according to notified data 1793-1424 infants with congenital defects were born in the years 1985-2000 (mean number per year 1627.7) with incidence of $20.01 / 10^{3} \mathrm{LB}$ $-14.46 / 10^{3}$ LB (1). Out of them orofacial clefts were present in $6.7 \%-4.84 \%$ (mean 5.92\%) with mean number 96.3 infants with OC per year $\left(1.33 \pm 0.041 / 10^{3} \mathrm{LB}\right)$. Orofacial clefts are important for the health impairment as well as longterm demanding complex therapy and health care lasting to the adultness. All the race and ethnic groups could suffer from these congenital anomalies with different incidence. In white population the risk of congenital OC was estimated with frequency 1 infant with OC per 500 live births as a result of abnormity in embryonal development of foetus during the 4 th to the 12 th week of pregnancy, i.e. the period important for development of structures of primary and secondary palates (2). Impairments could lead to clefts of primary palate, i.e. cleft of the lip (CL), secondary palate (CP), or both palates (CLP), or some of them combined with other anomalies-associated malformations (AM).

Objective of our study was to determine incidence rate of orofacial clefts in all regions of the Slovak Republic (SR).

\section{MATERIAL AND METHODS}

Data from all the patients with various types of orofacial clefts examined and operated on in the three departments specialized in plastic surgery in the years 1985-2000 were analysed in the study. Patients underwent surgery in Clinic of Plastic Surgery, Medical Faculty, Comenius University in Bratislava, Clinic of Plastic and Reconstructive Surgery in Košice, Department of Plastic, Estetic and Reconstructive Surgery in Banská Bystrica. Infants with OC were residents from Bratislava city (BA), the West Slovakia (WS), the Middle Slovakia (MS) and the East Slovakia regions (ES).

Using data from medical records and classification of orofacial clefts (OC) by Kernahan and Stark (3) occurrence of (OC) in percentage, incidence $/ 10^{3}$ live births (LB) per year, total incidence per $10^{3} \mathrm{LB}$ (TI) and mean incidence $/ 10^{3}$ in the defined period, frequency of OC by types, laterality, gender and seasonality were calculated. For statistical evaluation $\chi^{2}$ test was used.

These data were compared to notified morbidity rate per year, published by Institute of Health Information and Statistics of the Slovak Republic. 
Table 1. Children born with $O C^{a}$ in the regions of Slovakia in the years 1985-2000

\begin{tabular}{|c|c|c|c|c|c|c|c|}
\hline \multirow{2}{*}{$\begin{array}{c}\text { Types of } \\
\text { OC }^{\mathrm{a}}\end{array}$} & \multirow{2}{*}{ Gender } & \multicolumn{4}{|c|}{ Regions } & \multirow{2}{*}{ Total } & \multirow{2}{*}{$\%$} \\
\hline & & $\begin{array}{l}\text { BA- } \\
\text { city }\end{array}$ & WS $^{g}$ & MS $^{h}$ & ES $^{i}$ & & \\
\hline \multirow{3}{*}{$\mathrm{CL}^{\mathrm{b}}$} & males & 19 & 93 & 101 & 76 & 289 & 15.6 \\
\hline & females & 14 & 64 & 74 & 42 & 194 & 10.5 \\
\hline & total & 33 & 157 & 175 & 118 & 483 & 26.1 \\
\hline \multirow{3}{*}{ CLPc } & males & 30 & 128 & 157 & 138 & 453 & 24.5 \\
\hline & females & 14 & 79 & 111 & 91 & 295 & 16.0 \\
\hline & total & 44 & 207 & 268 & 229 & 748 & 40.5 \\
\hline \multirow{3}{*}{$C P^{d}$} & males & 24 & 71 & 92 & 65 & 252 & 13.6 \\
\hline & females & 26 & 101 & 136 & 81 & 344 & 18.6 \\
\hline & total & 50 & 172 & 228 & 146 & 596 & 32.2 \\
\hline \multirow{3}{*}{$A M^{e}$} & males & 1 & 3 & 7 & 3 & 14 & 0.8 \\
\hline & females & 0 & 3 & 4 & 1 & 8 & 0.4 \\
\hline & total & 1 & 6 & 11 & 4 & 22 & 1.2 \\
\hline \multirow{3}{*}{$\begin{array}{l}\text { Total } \\
\text { of } \mathrm{OC}^{\mathrm{a}}\end{array}$} & males & 74 & 295 & 357 & 282 & 1008 & 54.5 \\
\hline & females & 54 & 247 & 325 & 215 & 841 & 45.5 \\
\hline & total & 128 & 542 & 682 & 497 & 1849 & 100.0 \\
\hline
\end{tabular}

$\mathrm{OC}^{\mathrm{a}}$ - Orofacial clefts, $\mathrm{CL}^{\mathrm{b}}-$ Cleft lip, $C \mathrm{CP}^{\mathrm{c}}-$ Cleft lip + palate, $\mathrm{CP}^{\mathrm{d}}-$ Cleft palate $\mathrm{AM}^{\mathrm{e}}$ - Associated malformations, BA-city - Bratislava city, $\mathrm{WS}^{9}$ - West Slovakia region

$\mathrm{MS}^{\mathrm{h}}$ - Middle Slovakia region, $\mathrm{ES}^{\mathrm{i}}$ - East Slovakia region

\section{RESULTS}

1,849 children with OC underwent examination, surgery and treatment in the three specialized departments of plastic surgery in the Slovak Republic during the 16-years-period (1985-2000). $6.9 \%$ (128) children were residents from Bratislava city (BA), $29.3 \%$ (542) from the West Slovakia region (WS), 36.9\% (682) from the Middle Slovakia region (MS) and 26.9\% (497) from the East Slovakia region (ES). Among patients there were 54.5\% $(1,008)$ boys and $45.5 \%(841)$ girls, with preponderance of males in every region (Table 1, Table 2). More than 40\% (748) of children suffered from clefts of primary and secondary palate (CLP), more than $32 \%$ (596) of CP and about $26 \%$ (483) of CL (Fig.1). Associated malformations (AM) were seldom recognised, slightly more than $1 \%$ (Table 2).

\section{Total Incidence and Mean Incidence}

Of the 1,147,236 live born infants born in the Slovak Republic in the years 1985-2000 1,849 children were born with orofacial clefts, accounting for total incidence of $1.61 / 10^{3} \mathrm{LB}$. The highest incidence was of CLP $-0.65 / 10^{3} \mathrm{LB}$, comparing to the morbidity rate of $\mathrm{CP}-0.52 / 10^{3} \mathrm{LB}$ and $\mathrm{CL}-0.42 / 10^{3} \mathrm{LB}$. The lowest incidence of OC was detected among children with AM $-0.02 / 10^{3} \mathrm{LB}$ (Table 2). Mean incidence was almost equal -1.62 $\pm 0.057 / 10^{3} \mathrm{LB}$.

\section{Annual Incidence}

Determinating statistical significance by test of homogeneity at the $p$-value $=0.05$ we revealed significant differences between
Table 2. Total incidence of OC ${ }^{a}$ per $10^{3}$ live births in Slovakia in the years 1985-2000

\begin{tabular}{|c|c|c|c|c|c|c|}
\hline \multirow{2}{*}{$\begin{array}{c}\text { Types of } \\
\mathrm{OC}^{\mathrm{a}}\end{array}$} & \multirow{2}{*}{ Gender } & \multicolumn{4}{|c|}{ Regions } & \multirow{2}{*}{$\begin{array}{l}\text { Total } \\
\text { inci- } \\
\text { dence }\end{array}$} \\
\hline & & $\begin{array}{l}\text { BA- } \\
\text { city }\end{array}$ & WS $^{g}$ & MS $^{\mathrm{h}}$ & $E S^{i}$ & \\
\hline \multirow{3}{*}{$\mathrm{CL}^{\mathrm{b}}$} & males & 0.51 & 0.54 & 0.56 & 0.39 & 0.49 \\
\hline & females & 0.39 & 0.39 & 0.43 & 0.22 & 0.35 \\
\hline & total & 0.45 & 0.47 & 0.49 & 0.31 & 0.42 \\
\hline \multirow{3}{*}{ CLPc $^{c}$} & males & 0.80 & 0.74 & 0.87 & 0.70 & 0.77 \\
\hline & females & 0.39 & 0.48 & 0.64 & 0.48 & 0.53 \\
\hline & total & 0.60 & 0.62 & 0.76 & 0.60 & 0.65 \\
\hline \multirow{3}{*}{$\mathrm{CP}^{\mathrm{d}}$} & males & 0.64 & 0.41 & 0.51 & 0.33 & 0.43 \\
\hline & females & 0.72 & 0.62 & 0.79 & 0.43 & 0.61 \\
\hline & total & 0.68 & 0.51 & 0.64 & 0.38 & 0.52 \\
\hline \multirow{3}{*}{$\mathrm{AM}^{\mathrm{e}}$} & males & 0.03 & 0.02 & 0.04 & 0.02 & 0.02 \\
\hline & females & 0.00 & 0.02 & 0.02 & 0.01 & 0.01 \\
\hline & total & 0.01 & 0.02 & 0.03 & 0.01 & 0.02 \\
\hline \multirow{3}{*}{$\begin{array}{l}\text { Total } \\
\text { incidence }\end{array}$} & males & 1.97 & 1.71 & 1.97 & 1.43 & 1.71 \\
\hline & females & 1.50 & 1.51 & 1.88 & 1.15 & 1.50 \\
\hline & total & 1.74 & 1.61 & 1.93 & 1.29 & 1.60 \\
\hline
\end{tabular}

$\mathrm{OC}^{\mathrm{a}}$ - Orofacial clefts, $\mathrm{CL}^{\mathrm{b}}-$ Cleft lip, $C \mathrm{PP}^{\mathrm{c}}-$ Cleft lip + palate, $C \mathrm{P}^{\mathrm{d}}-$ Cleft palate, $\mathrm{AM}^{\mathrm{e}}$ - Associated malformations, BA-city - Bratislava city, $\mathrm{WS}^{\mathrm{g}}$ - West Slovakia region,

$\mathrm{MS}^{\mathrm{h}}$ - Middle Slovakia region, ESi - East Slovakia region

incidences of $\mathrm{OC}$ in these 16 years. The lowest incidence was observed in $1985\left(1.19 / 10^{3}\right.$ LB) and the highest was in 1994 $\left(2.09 / 10^{3} \mathrm{LB}\right)$, followed by higher incidences also in the years $1992\left(2.01 / 10^{3}\right)$ and $1990\left(1.75 / 10^{3}\right)$ (Fig. 2).

\section{Distribution of OC according to Gender and Types}

Sex ratio was 1.14:1 with significant preponderance of males (TI $\left.-1.71 / 10^{3}\right)$, in females the total incidence was $1.50 / 10^{3} \mathrm{LB}$ (Table 2). The boys suffered significantly more from CLP (ratio

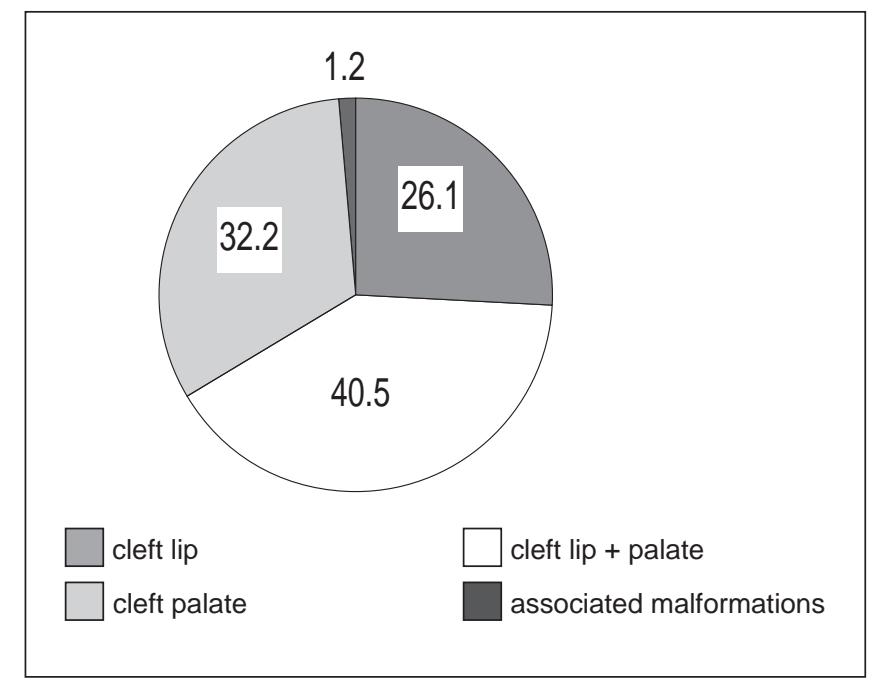

Fig.1. Types of orofacial clefts-percentage (\%) in Slovakia in the years 1985-2000. 


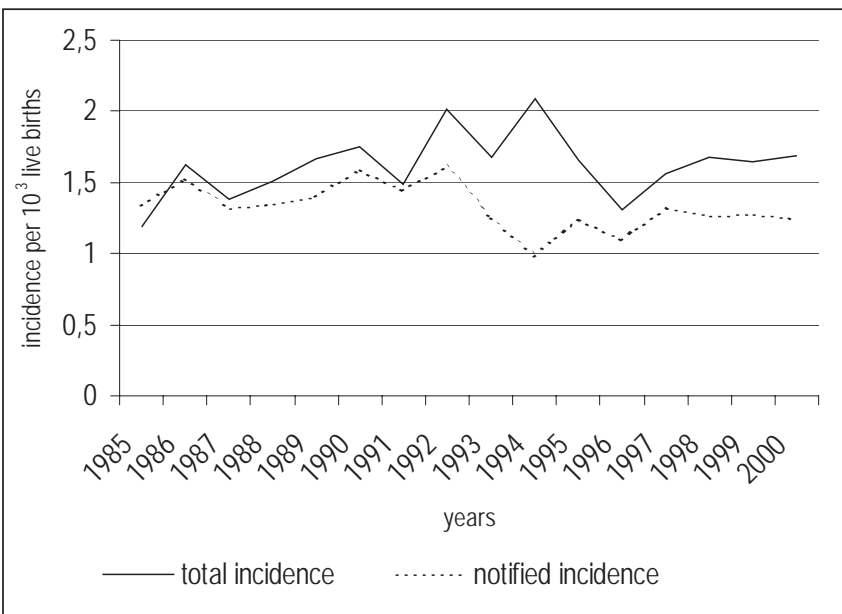

Fig.2. Orofacial clefts - total and notified incidences per $10^{3}$ live births in Slovakia in the years 1985-2000.

1.45:1) and CL (1.49:1) than the girls. Incidence of CP was in girls 1.42 times higher than in boys, sex ratio 0.71:1.

\section{Distribution of OC according to Laterality}

Among children with CL type unilateral clefts were more common (89\%), left- sided clefts $(67.4 \%)$ with higher rate. Similarly, unilateral clefts were more often detected in children with CLP (68.7\%), also with higher frequency left-sided clefts than rightsided in ratio $66.5 \%: 33.5 \%$.

\section{Geographical Distribution}

Significant differences in incidence of OC were detected by test of homogeneity in various regions and districts of Slovakia. The highest incidence was detected in MS (TI 1.93/10 3 LB), less in BA-city $\left(1.74 / 10^{3} \mathrm{LB}\right)$, followed by incidence in WS $\left(1.61 / 10^{3}\right.$ LB) and the lowest occurence of OC was detected in ES $\left(1.29 / 10^{3}\right.$ LB) during the studied period of 16 years.

In districts of Slovakia incidences of clefts differed, the highest rate was documented in the west of Slovakia (district in suburbs of Bratislava $-2.11 / 10^{3} \mathrm{LB}$, Senica $-1.97 / 10^{3} \mathrm{LB}$ ), in the south of Slovakia (Komárno $-2.0 / 10^{3} \mathrm{LB}$ ) but also in the north and in the middle of Slovakia (Čadca $-2.27 / 10^{3}$, Považská Bystrica $-2.13 / 10^{3}$, Žiar nad Hronom $-2.12 / 10^{3}$, Dolný Kubín $-2.09 / 10^{3}$ ) and in the district Svidník - 2.05/10 LB in the east of Slovakia.

\section{Seasonal Fluctuations}

There were no significant differences in seasonal variation, higher incidence of OC was noted in February $\left(1.87 / 10^{3} \mathrm{LB}\right)$, in November and September $\left(1.74 / 10^{3} \mathrm{LB} ; 1.72 / 10^{3} \mathrm{LB}\right)$.

\section{Comparison of Detected Incidence of OC with Notified Data}

During studied period of 16 years the number of children with clefts from register of OC in SR reported 1,541 children with OC whilst in our study 1,849 children were found to suffer from any types of orofacial clefts. When comparing the oficial reported data in the years 1985-2000 with data from our active survey it was found out that oficial register missed 17\% (308) children with OC, who were not notified.
In view of our results we propose that estimated risk of clefts in newborns in Slovakia is higher (1 child with OC per 620 LB), stipulating total incidence $1.61 / 10^{3} \mathrm{LB}$, than that calculated from register of notified cases ( 1 child with OC per $746 \mathrm{LB}$ ) which determines total incidence $1.34 / 10^{3} \mathrm{LB}$.

Comparing mean annual incidence determined by our study $\left(1.62 \pm 0.057 / 10^{3} \mathrm{LB}\right)$ to notified data $\left(1.33 \pm 0.041 / 10^{3} \mathrm{LB}\right)$ higher occurrence of OC was revealed.

\section{DISCUSSION}

Occurrence of orofacial clefts varies in geographical distribution, by race and ethnic differences. Generally, higher risk of clefts in newborns has been found in Orient than in Caucasians, in white race population than in black population, although with high range of differences among countries $(2,4,5)$. In a larger geographic area, e.g. in Arabic population, various incidences of congenital clefts can be recognized resembling multifactorial etiology of these malformations, including genetic, ethnic but also exogenic factors. Low incidences of OC were reported from Saudi Arabi (Riyadh ) $0.3 / 10^{3} \mathrm{LB}$ (6), from Kuwait more than $1.5 / 10^{3}(6)$, from Iran $1.03 / 10^{3}(7)$, from Jordan $1.39 / 10^{3}(8)$, unlike the higher incidence of OC reported from Al-Gassime 2.19/103 LB (9).

Precise longterm follow-up in certain regions with documentation of all irregular peaks with high morbidity rate is needed (2), to find an explanation for differences in occurrence of these congenital defects and presumable role of all possible etiologic factors.

Orofacial clefts occur with wide range all over the world (10). In Europe, higher incidences of OC were detected in Poland and Sweden $\left(2.0 / 10^{3}\right)(11,12)$, in Bohemia $\left(1.86 / 10^{3} \mathrm{LB}\right)$ and in the former Czechoslovakia $\left(1.81 / 10^{3} \mathrm{LB}\right)(13,10)$, followed by Switzerland $\left(1.86 / 10^{3}\right)(14)$, Magdeburg region in Germany $\left(1.85 / 10^{3}\right)(15)$, France $\left(1.75 / 10^{3}\right)$, Finlandia $\left(1.74 / 10^{3}\right)$, Denmark $\left(1.69 / 10^{3}\right)(10)$, Slovenia and Hungary with similar incidences of $1.64 / 10^{3}$ LB $(16,17)$.

Lower morbidity rates of OC were reported in Belgium, the Netherlands $\left(1.47 / 10^{3}\right)$, Italy $\left(1.33 / 10^{3}\right)$, Scotland $\left(1.4 / 10^{3}\right)$ and Ireland $\left(1.28 / 10^{3} \mathrm{LB}\right)(10,18,19)$.

Lower occurrence of orofacial clefts were reported in America, in California $1.12 / 10^{3}$ and in South America $1.0 / 10^{3}$ LB (10) as well.

According to the results of the presented study on morbidity rate of OC in Slovakia during the years 1985-2000 and in accordance with previous partial findings in some parts of the republic $(20,21)$, Slovakia could belong to the countries with high incidence of these congenital malformations. The highest rate of OC in the central part of Slovakia reaching even $1.868 / 10^{3} \mathrm{LB}$ during previous study (1985-1994 years) was confirmed by the current study when the total incidence reached $1.93 / 10^{3} \mathrm{LB}$. The lowest incidence $\left(1.29 / 10^{3} \mathrm{LB}\right)$ was documented in the eastern part of Slovakia, not reported previously.

Retrospective analysis of differences between regions and districts will be completed and supplemented by analysis of questionnaires targeted to exogenic factors, which might clarify differences found. The most common type of OC was CLP - in accordance with other authors (5), followed by CP and CL. Similar as in other references $(22,23)$ orofacial clefts were more frequent 
in boys than in girls (sex ratio 1.14:1). Males suffer more from CLP and CL (24) and in females more common are clefts of type CP. This sexual dimorphism is explained by higher resistance of females to development of CLP and CL, however in females there is a "hidden" disposition to occurrence of CP. Theoretically, in males there is over twice higher tendency to development of CL and CLP during embryogenesis than in females (23). On the contrary, in females development of $\mathrm{CP}$ is more frequent. In our study sex ratio was 0.71:1.

Unilateral clefts prevailed bilateral clefts in $72 \%$, almost twice prevailed left-sided to right-sided clefts, without any sex preponderance. Similar results were found in the former Czechoslovakia (22).

Significantly higher incidence of OC in children born in the years 1990, 1992 and 1994 is difficult to explain. There were higher morbidity rates of acute respiratory diseases, including influenza, in the first months of these years. Role of some infections in etiology of OC is well known, but we did not do any investigations to confirm this relation.

Seasonal variations of $\mathrm{OC}$ in several countries are described by many authors $(25,26)$. In our 16 -year-study we observed nonsignificantly higher rate in winter and fall, some references recognised similar patterns.

Presented study indicated actual risk of OC for newborns in Slovakia, and difference of approximately $17 \%$ with regard to oficial data was found. Similar disaccordance was noticed also by Czech authors (2). Actual incidence could be even higher when also dead infants with OC or those who died prior visiting specialised ambulatory care will be included. Czech authors detected about $10 \%$ stillbirths or deaths in early life among infants with OC (23).

These facts underline the importance of precise notification and exact database of children with OC for detection of real occurrence of these congenital defects.

\section{REFERENCES}

1. Institute of Health Information and Statistics. Congenital Defects in SR 1985 - 2000. Bratislava: IHIS, Slovak Republic; 1986 - 2001. (In Slovak.)

2. Tolarová M. Incidence of orofacial clefts in Bohemia from 1975 to 1982. Cesk Pediatr. 1986 Mar;41(3):131-5. (In Czech.)

3. Kernahan DA, Stark RB. A new classification for cleft lip and palate. Plast Reconstr Surg. 1958 Nov;22(5):435-41.

4. Taher AA. Cleft lip and palate in Tehran. Cleft Palate Craniofac J. 1992 Jan;29(1):15-6.

5. Croen LA, Shaw GM, Wasserman CR, Tolarova MM. Racial and ethnic variations in the prevalence of orofacial clefts in California, 1983-1992. Am J Med Genet. 1998 Aug 27; 79(1):42-7.

6. Kumar P, Hussain MT, Cardoso E, Hawary MB, Hassanain J. Facial clefts in Saudi Arabia: an epidemiologic analysis in 179 patients. Plast Reconstr Surg. 1991 Dec;88(6):955-8.
7. Rajabian MH, Sherkat M. An epidemiologic study of oral clefts in Iran: analysis of 1,669 cases. Cleft Palate Craniofac J. 2000 Mar;37(2):191-6.

8. Al Omari F, Al-Omari IK. Cleft lip and palate in Jordan: birth prevalence rate. Cleft Palate Craniofac J. 2004 Nov;41(6):609-12.

9. Borkar AS, Mathur AK, Mahaluxmivala S. Epidemiology of facial clefts in the central province of Saudi Arabia. Br J Plast Surg. 1993 Dec;46(8):673-5.

10. Derijcke A, Eerens A, Carels C. The incidence of oral clefts: a review. Br J Oral Maxillofac Surg. 1996 Dec;34(6):488-94.

11. Antoszewski B, Kruk-Jeromin J. Epidemiology of cleft lip and palate in Lodz, Poland, in the years 1981-1995. Acta Chir Plast. 1997;39(4): 109-12.

12. Hagberg C, Larson O, Milerad J. Incidence of cleft lip and palate and risks of additional malformations. Cleft Palate Craniofac J. 1998 Jan;35(1):40-5.

13. Peterka M, Peterkova R, Tvrdek M, Kuderova J, Likovsky Z. Significant differences in the incidence of orofacial clefts in fifty-two Czech districts between 1983 and 1997. Acta Chir Plast. 2000;42(4):124-9.

14. Addor MC, Feldmeyer L, Hohlfeld J, Schorderet DF. Epidemiology of lip-maxilla-palate clefts in the canton of Vaud. Rev Med Suisse Romande. 2003 Aug;123(8):501-5. (In French.)

15. Rosche C, Steinbicker V, Rose I. Incidence of facial clefts in the Magdeburg region. Mund Kiefer Gesichtschir 1998 Jan;2(1):5-10. (In German.)

16. Kozelj V. Epidemiology of orofacial clefts in Slovenia, 1973-1993: comparison of the incidence in six European countries. J Craniomaxillofac Surg. 1996 Dec;24(26):378-82

17. Czeizel AE, Hirschberg J. Orofacial clefts in Hungary. Epidemiological and genetic data, primary prevention. Folia Phoniatr Logop. 1997;49(34):111-6.

18. Bellis TH, Wohlgemuth B. The incidence of cleft lip and palate deformities in the south-east of Scotland (1971-1990). Br J Orthod. 1999 Jun;26(2):121-5.

19. Gregg T, Boyd D, Richardson A. The incidence of cleft lip and palate in Nothern Ireland from 1980-1990. Br J Orthod. 1994 Nov;21(4):387-92.

20. Macháčová E, Špaleková M, Brozman M, Hajdů E. An Epidemiological Study of Cleft Lip and Palate in Slovakia. Surg Childh Intern. 2000; 8:103-107.

21. Macháčová E, Bánsky R, Špaleková M, Fedeleš J, Kroupová D. Orofacial clefts in western Slovakian regions. Epidemiol Mikrobiol Imunol. 2002;51(4):165-168. (In Slovak)

22. Tolarova M. Orofacial clefts in Czechoslovakia. Incidence, genetics and prevention of cleft lip and palate over a 19-year-period. Scand J Plast Reconstr Surg Hand Surg. 1987;21(1):19-25.

23. Černý M, Fára M, Hrivň́ková J, Moucha L. Cleft lip and palate: Variability in the Czech population, sex ratio and familial incidence. Rozhl Chir. 1986 Oct;65(10):653-62. (In Czech.)

24. Janovič J, Fedeleš J, Zboja Š. Current opinions on the complex treatment of cleft lip and palate. Lek Obz. 1997; 46:38-41. (In Slovak.)

25. Cooper ME, Stone RA, Liu Y, Hu DN, Melnick M, Marazita ML. Descriptive epidemiology of nonsyndromic cleft lip with or without cleft palate in Shanghai, China, from 1980 to 1989. Cleft Palate Craniofac J. 2000 May;37(3):274-80.

26. Wang SL, Huang CS, Chen YR, Noordhoff MS. Cleft lip and cleft palate in the Craniofacial Center, Chang Gung Memorial Hospital: incidence, sex, seasonality and topographic distribution. Changgeng Yi Xue Za Zhi. 1989 Dec 20;12(4):215-24. (In Chinese.) 